\title{
Evaluation of pain of neonates during invasive procedures in intensive care
}

\section{Avaliação da dor de recém-nascidos durante procedimentos invasivos em terapia intensiva}

\author{
Cibele Thomé da Cruz ${ }^{1}$, Joseila Sonego Gomes², Rosane Maria Kirchner ${ }^{3}$, Eniva Miladi Fernandes Stumm²
}

DOI 10.5935/1806-0013.20160070

\section{ABSTRACT}

BACKGROUND AND OBJECTIVES: Neonates do not verbalize pain, so it is up to health professionals involved with their assistance to be qualified to evaluate pain during invasive procedures to plan relief strategies. This study aimed at evaluating pain in neonates admitted to a neonatal intensive care unit during invasive procedures.

METHODS: Crossover investigation with 34 neonates admitted to the intensive care unit of a general hospital, from December/2012 to February/2013. Data were collected with the Neonatal Infant Pain Scale and analyzed by descriptive statistics. RESULTS: Procedures triggering more pain were tracheal tube aspiration, airways and venous puncture. Babies had severe pain during tracheal intubation and passage of peripheral insertion central catheter.

CONCLUSION: Evaluating pain as the fifth vital sign with validated scale during invasive procedures is critical for planning and implementing ethic and humanized nursing assistance.

Keywords: Intensive care unit, Neonate, Pain measurement.

\section{RESUMO}

JUSTIFICATIVA E OBJETIVOS: Recém-nascidos não verbalizam a dor, desse modo, cabe aos profissionais de saúde envolvidos com o seu cuidado estarem aptos a avaliar a dor, diante de procedimentos invasivos para planejar estratégias de alívio. $\mathrm{O}$ objetivo deste estudo foi avaliar a dor de recém-nascidos internados em unidade de terapia intensiva neonatal durante a realização de procedimentos invasivos.

MÉTODOS: Investigação transversal, com 34 recém-nascidos internados na respectiva unidade de um hospital geral, de dezembro/2012 a fevereiro/2013. Os dados foram coletados por meio

1. Associação Hospital de Caridade de Ijuí, Unidade de Terapia Intensiva Neonatal, Ijuí, RS, Brasil.

2. Universidade Regional do Noroeste do Estado do Rio Grande do Sul, Departamento de Ciências da Vida, Ijuí, RS, Brasil.

3. Universidade Federal de Santa Maria - Campus CESNORS, Ijuí, RS, Brasil.

Submitted in February 10, 2016.

Accepted for publication in August 08, 2016.

Conflict of interests: none - Sponsoring sources: none.

Correspondence to:

Cibele Thomé da Cruz

Rua Siqueira Couto, 1665 - Bairro Burtet

98700-000 Ijuí, RS, Brasil.

E-mail: cibelethome@bol.com.br

(C) Sociedade Brasileira para o Estudo da Dor de Escala de Avaliação da Dor para recém-nascidos, analisados com estatística descritiva.

RESULTADOS: Os procedimentos que mais desencadearam dor foram aspiração de tubo orotraqueal, vias aéreas e punção venosa. Os bebês apresentaram dor forte durante intubação orotraqueal e passagem de cateter central de inserção periférica. CONCLUSÁO: Avaliar a dor como quinto sinal vital, com escala validada, durante procedimentos invasivos é importante para planejar e implementar a assistência de enfermagem ética e humanizada. Descritores: Mensuração da dor, Recém-nascido, Unidade de terapia intensiva.

\section{INTRODUCTION}

The International Association for the Study of Pain (IASP) defines pain as a sensory, emotional and unpleasant experience associated to real or potential tissue injury. Pain has physiologic role and acts as a red flag for the perception of something threatening body integrity ${ }^{1}$.

Children and neonate (NN) pain management is complex. It involves elements related to children, health professional and their relatives. It is also critical that parents participate in the evaluation and intervention process for pain relief, because they know their children ${ }^{2}$.

Preterm neonates (PTNN) receive, in average, approximately 130 to 234 manipulations in the first 24h, many of them painful. Acute painful stimuli in NN trigger a stress response which includes changes at cardiovascular, respiratory, immune, hormonal and behavioral level, among others. These physiologic responses are followed by stress endocrine-metabolic reaction with hormones release such as epinephrine, norepinephrine and cortisol, and may result in hyperglycemia and lipid protein catabolism, which interferes with homeostatic balance which is already precarious in $\mathrm{PTNN}^{3}$.

So, skin conductivity measurement as tool to measure pain and discomfort during invasive procedures in neonatal intensive care units (NICU) shows that, in spite of the use of sedation and analgesia, NN feel pain and discomfort associated to therapeutic and diagnostic procedures ${ }^{4}$.

Professionals know how much PTNN admission to NICU is associated to numerous procedures, such as venous punctures, orogastric and vesical catheters, capillary glycemia, dressings, airways aspiration and tracheal intubation, which may trigger discomfort, stress and pain. In addition, there are noises, bright and continuous lights and constant handling. In this sense, nursing teams evaluate PTNN pain by means of physiologic and behavioral changes. 
Physiologic changes are tachypnea, tachycardia, decreased oxygen saturation, increased blood pressure, intracranial pressure and palmar sweating; behavioral changes are body movements, facial expression, sleep pattern, vigil and cry $^{5}$. It is important that the multiprofessional team evaluate NN pain based on scientific evidences, added to the development of institutional pain control policies, use of validated measurement tools, as well as analgesia protocols and ongoing education at work.

In light of the above, this study aimed at evaluating pain of $\mathrm{NN}$ submitted to invasive procedures, by means of a validated scale.

\section{METHODS}

This is a quantitative, descriptive, crossover study carried out in a NICU of a non-for-profit hospital size IV, from the Northwestern region of the state of Rio Grande do Sul. This unit has 8 neonatal beds for the Single Health System (SUS). Team is made up of nine pediatricians, one coordinator nurse, six assistant nurses, 28 nursing technicians, three physiotherapists and one clerk.

Participated in the study $34 \mathrm{NN}$ admitted to the referred unit in December 2012 and January and February 2013. Pain was evaluated associated to the following invasive procedures: venous puncture, tracheal aspiration, peripheral capillary glycemia test, intubation, orogastric probe, peripheral insertion

Table 1. Pain evaluation with Neonatal Infant Pain Scale

\begin{tabular}{lccc}
\hline Parameters & 0 point & 1 point & 2 points \\
\hline Facial expression & Relaxed & Contracted & - \\
Cry & Absent & Mumbling & Vigorous \\
Breathing & Relaxed & Different than basal & - \\
Arms & Relaxed & Flexed/ & - \\
& & stretched & \\
Legs & Relaxed & Flexed/ & - \\
& & stretched & \\
Alertness & Sleeping/ & Uncomfortable & - \\
& calm & & \\
\hline
\end{tabular}

central catheter (PICC), and chest drainage. As from this evaluation, pain intensity in studied $\mathrm{NN}$ was related to the technical procedure.

Data collection tool was Neonatal Infant Pain Scale (NIPS) which evaluates children's pain based on the following behavioral and physiologic parameters: facial expresssion, cry, breathing, arms, legs and alertness ${ }^{6}$.

Table 1 shows pain evaluation by NIPS.

Participated in the study all preterm, term, post-term and infant NN admitted to the NICU during the data collection period. NN pain was evaluated by nursing professionals, nurses and nursing technicians during invasive procedures.

It has to be highlighted that such professionals were qualified for pain evaluation with NIPS and a pilot test was performed where the researcher has followed and jointly evaluated pain, aiming at qualification to answer questions and prevent evaluation mistakes.

Data were analyzed with descriptive statistics and software SPSS 17.0. Results are shown in crossed tables.

All ethic recommendations for human research were complied with, according to Resolution 466/2012 of the National Health Council.

This study was approved by the Research Ethics Committee, Unijuí, Opinion no 177.690 from 12/19/2012.

\section{RESULTS}

From $34 \mathrm{NN}$ participating in the study, $35.3 \%$ (12) were females and $64.7 \%(22)$ were males. As to gestational age, most, $70.6 \%$ (24) were preterm and the others $29.4 \%$ (10) were term NN.

Table 2 shows NN pain evaluation during technical procedures, according to gestational age. There, NN were classified in preterm and term. It is observed that tracheal and/or airways aspirations were procedures causing most NN pain. However, venous puncture had the highest percentage of moderate to severe pain.

Still with regard to table 2, it was observed that peripheral capillary glycemia test in preterm $\mathrm{NN}$ has induced mild, moderate and severe pain, with high percentages for moder-

Table 2. Neonates pain evaluation during invasive procedures, according to age

\begin{tabular}{|c|c|c|c|c|c|}
\hline Age & Procedures & Mild pain $\mathrm{n}(\%)$ & Moderate pain $\mathrm{n}(\%)$ & Severe pain $n(\%)$ & Total $n(\%)$ \\
\hline \multirow{4}{*}{$\begin{array}{l}\text { Preterm } \\
\text { NN }\end{array}$} & TT or AW aspiration & $1(4.4)$ & $9(39.1)$ & $13(56.5)$ & $23(100)$ \\
\hline & Venous puncture & - & $6(28.5)$ & $15(71.4)$ & $21(100)$ \\
\hline & Intubation & - & $1(50)$ & $1(50)$ & $2(100)$ \\
\hline & Orogastric probe & - & $1(11.1)$ & $8(88.8)$ & $9(100)$ \\
\hline \multirow{3}{*}{ Term NN } & Venous puncture & - & $2(50)$ & $2(50)$ & $4(100)$ \\
\hline & Peripheral capillary glycemia test & - & $2(66.6)$ & $1(33.3)$ & $3(100)$ \\
\hline & Intubation & - & - & $1(100)$ & $1(100)$ \\
\hline
\end{tabular}

$\overline{\mathrm{NN}}=$ neonate $\mathrm{TT}$ = tracheal tube; $\mathrm{AW}$ = airways; $\mathrm{PICC}=$ peripheral insertion central catheter. 
Table 3. Neonate pain evaluation during invasive procedures, according to gender

\begin{tabular}{|c|c|c|c|c|c|}
\hline & Procedures & Mild pain $\mathrm{n}(\%)$ & Moderate pain $\mathrm{n}(\%)$ & Severe pain $n(\%)$ & Total $\mathrm{n}(\%)$ \\
\hline \multirow[t]{5}{*}{ Female } & $\mathrm{TT}$ or $\mathrm{AW}$ aspiration & $4(21)$ & $11(58)$ & $4(21)$ & 19(100) \\
\hline & Venous puncture & - & $5(45.4)$ & $6(54.5)$ & 11(100) \\
\hline & Peripheral capillary glycemia test & $1(8.3)$ & $7(58.3)$ & $4(33.3)$ & 12(100) \\
\hline & Intubation & - & - & $2(100)$ & $2(100)$ \\
\hline & Orogastric probe & - & - & $2(100)$ & $2(100)$ \\
\hline \multirow[t]{6}{*}{ Male } & $\Pi \mathrm{T}$ or $\mathrm{AW}$ aspiration & - & $4(28.6)$ & $10(71.4)$ & 14(100) \\
\hline & Venous puncture & - & $3(21.4)$ & $11(78.6)$ & 14(100) \\
\hline & Peripheral capillary glycemia test & $2(22.2)$ & $2(22.2)$ & $5(55.5)$ & $9(100)$ \\
\hline & Intubation & - & $1(100)$ & - & $1(100)$ \\
\hline & Orogastric probe & - & $1(50)$ & $1(50)$ & $2(100)$ \\
\hline & PICC insertion & - & $1(100)$ & - & $1(100)$ \\
\hline
\end{tabular}

$\overline{\mathrm{TT}}=$ tracheal tube; $\mathrm{AW}=$ airways; $\mathrm{PICC}=$ peripheral insertion central catheter .

ate to severe pain; term NN had high percentage of moderate pain during this procedure. During orogastric probe, predominant pain among studied NN was classified as severe. Table 3 shows pain evaluation during NN procedures according to gender. It is observed that when submitted to TT and/or AW aspiration, venous puncture, peripheral capillary glycemia test, orogastric probe and intubation male NN had higher percentage of severe pain as compared to female NN.

\section{DISCUSSION}

Results are in line with the literature which shows that the incidence of preterm $\mathrm{NN}$ is higher than term $\mathrm{NN}^{7}$. So, therapeutic treatment in this initial phase of life significantly influences quality of life of these babies. In their vast majority PTNN need ventilation support, and tracheal and airways aspiration is needed to maintain their patency.

A study using preterm pain profile scale (PIPP) in NN submitted to tracheal aspiration ${ }^{8}$ has shown that they had pain during tracheal cannula aspiration identified by behavioral and physiologic reactions: bulge forehead, squeezed eyes, deepened nasolabial groove, changed heart rate and oxygen saturation. So, tracheal aspiration, in addition to being painful, is invasive, thus requiring evaluation of the need to perform such procedure.

Research $^{9}$ has evaluated preterm and term NN pain in Chinese hospitals when exposed to painful procedures. Most procedures were performed in the first three days. Preterm NN with gestational age of 28 and 29 weeks had more pain that those of 30 weeks or more gestational age $(\mathrm{p}<0.001)$. Tracheal aspiration was the most common procedure in preterm NN and venous puncture was the most common in term NN. In addition, tracheal intubation and femoral venous puncture were the most painful procedures. However, no painful procedure was followed by analgesia.

Venous puncture is essential and frequently performed in NN admitted to $\mathrm{NICU}^{10}$, and this was the procedure most triggering moderate to severe pain in studied NN. This is considered one of the most difficult and routine practices in $\mathrm{NN}^{9}$. So, nursing professionals' agility at venous puncture, organization, material preparation and concern with the number of puncture attempts in preterm NN are measures which may optimize the procedure, thus decreasing pain.

A comparative study to evaluate pain intensity in 24 preterm NN admitted to the NICU, during arterial blood collection, using NIPS ${ }^{11}$, where each one was its own control, has used $25 \%$ glucose and distilled water in babies two minutes before collection. Authors have described that this strategy has allowed NN to be more relaxed during painful stimulus, and physiologic changes have not varied in both groups. Behavioral changes were directly related to pain intensity during the painful procedure.

Another investigation evaluating preterm NN pain during venous puncture with NIPS, has shown that $31 \%$ had pain ${ }^{12}$. This result is in line with our study. Authors have shown that preterm NN pain evaluation and management need integral nursing care during procedures, regardless of complexity; in addition pain should be also appreciated as a vital sign of clinical importance.

A study has evaluated $49 \mathrm{NN}$ of different ages as to self-regulation abilities in response to painful stimuli and associations between behavioral and cardiovascular responses during heel puncture for blood collection ${ }^{13}$. Children aged 28-31 and 3234 gestational weeks at birth were evaluated. Authors have stated the both groups had behavioral and cardiovascular indications of stress in response to blood collection; however younger gestational age NN (28-31 weeks) were physiologically more reactive.

Results of our study of pain evaluation during invasive procedures point to the importance of nurses acting in the respective unit to adequately prepare the nursing team. This preparation includes theoretical basis on pain, added to technical update of procedures performed in NN. The result of a study characterizing a nursing team and which has identified ways to evaluate and handle preterm NN pain, with 42 nursing professionals, contributes to this reflection. Studied team has 
shown knowledge about neonate pain and PTNN ability to feel even more pain than term NN. They referred using pain evaluation scales, among them NIPS ${ }^{14}$.

Authors emphasized that the team, in diagnosing pain, should adopt non-pharmacological measures of positioning/handling and non-nutritive sucking for pain relief and PTNN organization. And, after respective interventions, have re-evaluated PTNN to check the efficacy of the intervention. Moreover, the studied team has evaluated venous puncture and excessive manipulation/repositioning as most painful NN procedures and these results are in line with our study.

With regard to pain at PICC insertion, our results show that this triggers severe pain in NN and this result is in line with a study where authors have measured pain during catheter insertion and compared since venous puncture to its progres$\operatorname{sion}^{15}$. NN pain has varied from moderate to severe. As from these results, it is considered that, faced to the impossibility of avoiding painful invasive procedures, it is important to prevent negative procedure effects, added to strategies for pain control, especially non-pharmacological strategies, to minimize the worsening of $\mathrm{NN}$ clinical state.

In our study, $\mathrm{NN}$ pain during orogastric probe was evaluated as severe. In this sense, a study ${ }^{16}$ has found similar result. In light of such results, one should stress the need for professionals to be judicious when evaluating the indication of this and other procedures, as well as of using strategies to minimize or relief pain.

A study ${ }^{17}$ with 32 nurses of a neonatal unit of a private hospital of the city of Sáo Paulo, has tried to identify how they evaluated NN pain. It has shown that most widely used parameters for pain evaluation were: facial expression and cry, followed by vital signs changes, agitation and parameters used by NIPS. They mentioned as pharmacological methods to relief pain non-steroid anti-inflammatory drugs, potent opioids and sedatives. And as non-pharmacological methods change in position, local massage, non-nutritive sucking or gloved finger and immersion bath.

So, it is important to reflect about pain diagnosis of $\mathrm{NN}$ who cannot verbalize pain. It is suggested to know and implement in healthcare services validated pain evaluation scales according to specificity and individuality of each patient. And more, that these professionals be able to apply non-pharmacological methods for pain management, thus promoting humanized assistance.

\section{CONCLUSION}

Evaluating NN pain together with other vital signs, as well as during invasive procedures is mandatory in NICU to provide individualized and humanized care. In this sense, nurses are qualified professionals for the development of NN pain evaluation and management protocols together with ongoing education actions. These results are equally important to trigger nurses' reflections and actions aimed at implementing pain evaluation scales in intensive care units.

\section{REFERENCES}

1. Vitor AO, Ponte EL, Soares PM, Rodrigues ME, Lima RC, Carvalho KM, et al. Psicofisiologia da dor: uma revisão bibliográfica. RECIIS. Rev Eletr Com Inf Inov Saúde. 2008;2(1):87-96.

2. dos Santos MZ, Kusahara DM, Pedreira Mda L. [The experiences of intensive care nurses in the assessment and intervention of pain relief in children]. Rev Esc Enferm USP. 2012;46(5):1074-81. Portuguese.

3. Santos LM, Pereira MP, Santos LF, Santana RC. Avaliação da dor no recém-nascido prematuro em Unidade de Terapia Intensiva. Rev Bras Enferm, Brasilia. 2012;65(1):27-33

4. Karpe J, Misiołek A, Daszkiewicz A, Misiołek H. Objective assessment of pain-related stress in mechanically ventilated newborns based on skin conductance fluctuations. Anaesthesiol Intensive Ther. 2013;45(3):134-7.

5. Freitas ZM, Pereira CU, Oliveira DM. Escalas para avaliação de dor em neonatologia e sua relevância para a prática de enfermagem. Pediatria Moderna. 2012;12(68):18-24.

6. Silveira MF, Santos IS, Barros AJ, Matijasevich A, Barros FC, Victora CG. [Increase in preterm births in Brazil: review of population-based studies]. Rev Saude Publica. 2008;42(5):957-64. Portuguese.

7. Araújo MC, Nascimento MA, Christoffel MM, Antunes JC, Gomes AV. Aspiraçáo traqueal e dor: reaçôes do recém-nascido pré-termo durante o cuidado. Ciênc Cuid Saúde. 2010;9(2):255-61.

8. Pacheco ST, Silva AM, Lioi A, Rodrigues TA. O cuidado pelo enfermeiro ao recémnascido prematuro frente à punção venosa. Rev Enferm UERJ. 2012;20(3):306-11.

9. Chen M, Shi X, Chen Y, Cao Z, Cheng R, Xu Y, et al. A prospective study of pain experience in a neonatal intensive care unit of China. Clin J Pain. 2012;28(8):700-4.

10. Cruz CT da, Stübe M, Benetti ER, Gomes JS, Kirchner RM, Stumm EM. Evaluation of pain in newborns hospitalized to a neonatal intensive care unit. Rev Nurs UFPE. Recife, 2015;9(7):8504-11.

11. Silva TM, Chaves EM, Cardoso MV. Dor sofrida pelo recém-nascido durante a punçăo arterial. Esc Anna Nery Rev Enferm. 2009;13(4):726-32.

12. Santos LM, Silva TP, Santana RC, Matos KK. Sinais sugestivos de dor durante a punção venosa periférica em prematuros. Rev Enferm UFSM. 2012;2(1):1-9.

13. Lucas-Thompson R, Townsend EL, Gunnar MR, Georgieff MK, Guiang SF, Ciffuentes RF, et al. Developmental changes in the responses of preterm infants to a painful stressor. Infant Behav. 2008;31(4):614-23.

14. Amaral JB do, Resende TA, Contim D, Barichello E. Equipe de enfermagem diante da dor do recém-nascido pré-termo. Esc Anna Nery Rev Enf. 2014;18(2):241-6.

15. Costa P, Camargo PP, Bueno M, Kimura AF. Measuring pain in neonates during placement of central line catheter via peripheral insertion. Acta Paul Enferm. 2010;23(1):35-40

16. Santos JA, Procianoy RS, Bohrer BB, Noer C, Librelato GA, Campelo JN. [Do newborn infants feel pain when submitted to gastric suctioning?] J Pediatr. 2001;77(5):374-80. Portuguese.

17. Crescêncio EP, Zanelato S, Leventhal LC. Avaliaçăo e alívio da dor no recém-nascido. Rev Eletr Enf. 2009;11(1):64-9. 